University of Rhode Island

DigitalCommons@URI

2016

\title{
Why Ukraine and Russia Need Each Other
}

Nicolai Petro

University of Rhode Island, npetro@uri.edu

Follow this and additional works at: https://digitalcommons.uri.edu/psc_facpubs

The University of Rhode Island Faculty have made this article openly available.

Please let us know how Open Access to this research benefits you.

This is a pre-publication author manuscript of the final, published article.

Terms of Use

This article is made available under the terms and conditions applicable towards Open Access

Policy Articles, as set forth in our Terms of Use.

Citation/Publisher Attribution

Petro, Nicolai N. "Why Ukraine and Russia Need Each Other". Russian Politics 1.2: 184-202.

https://doi.org/10.1163/24518921-00102004

Available at: http://dx.doi.org/10.1163/24518921-00102004

This Article is brought to you for free and open access by the Political Science at DigitalCommons@URI. It has been accepted for inclusion in Political Science Faculty Publications by an authorized administrator of DigitalCommons@URI.For more information, please contact digitalcommons-group@uri.edu. 


\section{Why Ukraine and Russia Need Each Other}

Nicolai N. Petro

University of Rhode Island (USA)

NPetro@uri.edu

Abstract: The West's focus on corruption in Ukraine is largely misplaced. The main impediment to stability and economic growth is the government's suicidal choice to cut the country off from its main investor--Russia. This article looks at the economic and political costs of pursuing such a policy, and concludes that there is no alternative to Russian investment. Given the political and economic constraint imposed upon the European Union, the West and Russia need to work together to develop a comprehensive economic strategy that can promote Ukraine's economic development.

Keywords: Ukraine--Ukrainian Economy--Ukraine-Russia Relations--DCFTA--Eurasian Union

While the vast majority of Western politicians focus attention on the need to combat Ukraine's rampant corruption, a far more debilitating problem is being overlooked.

This problem is driving the country's dramatic economic collapse; it is antagonizing large segments of the population; it is alienating the country's largest pool of potential investors, and contributing to the growing sense of frustration with Ukraine in Western capitals. I am referring 
to the current government's ideologically driven choice to sever economic ties with Ukraine's major trading partner and chief investor, Russia.

In this paper I shall look at the damage being done by the government's choice to pursue what I call "suicide economics." Next, I will review why the DCFTA has proved to be much less of a benefit to Ukrainian than its supporters expected. Finally, I will argue that Ukraine still depends on Russia to achieve economic prosperity, and suggest ways to restore this vital link without compromising Ukraine's turn toward Europe.

\section{What is "Suicide Economics?"}

Ukraine's abysmal economic statistics since the transition of power in February 2014 are depressingly familiar. In the past 18 months living standards have fallen by half. ${ }^{1}$ Meanwhile inflation has risen to $43 \%$ annually, and public debt as a percentage of GDP has gone from $39.9 \%$ in 2013 , to $79 \%$ by the end of $2015 .{ }^{2}$ An estimated $55 \%$ of all economic activity simply goes unreported. ${ }^{3}$ In the financial sector, the share of toxic assets in bank portfolios is estimated

\footnotetext{
1 "Yushchenko: Ukraina v glubokom finansovom provale", Ukraina.ru, 24 January 2016, http://ukraina.ru/news/20160124/1015410916-print.html (accessed 26 March 2016); "Psevdootchet pravitelstva", Analitik, 9 February 2016, http://www.analitik.org.ua/current-comment/economy/56b8831c021fb/ (accessed 26 March 2016).

2 “Gosdolg Ukrainy pereshagnul predelnuyu otmetku po otnosheniyu k VVP”, Vesti Ukrainy, 12 February 2016, http://business.vesti-ukr.com/135875-gosdolg-ukrainy-pereshagnul-predelnuju-otmetku-po-otnosheniju-k-vvp (accessed 26 March 2016); Graham Phillips, "2 Years On - the 12 'Triumphs' of Euromaidan”, The Truth Speaker, 21 February 2016, http://thetruthspeaker.co/2016/02/21/2-years-on-the-12-triumphs-of-euromaidan/ (accessed 26 March 2016).

3 "Yushchenko: Poroshenko otkryl vtoroi front voiny", Vesti Ukrainy, 19 February 2016, http://vestiukr.com/strana/136795-juwenko-poroshenko-otkryl-vtoroj-front-vojny (accessed 26 March 2016).
} 
to exceed $50 \%$, while deposit withdrawals by households in 2014 reached $30 \%$ of total deposits. ${ }^{4}$ In 2014 financial flows into UA fell by $21 \%$, then by another $35 \%$ in $2015 .{ }^{5}$

What does this mean in terms of family buying power? If annual incomes under former president Viktor Yanukovych were roughly $\$ 3500$ dollars, they are now $\$ 2000$ according to Ukraine's first president, Leonid Kravchuk. ${ }^{6}$ The percentage of people who say that they do not have enough money for food, went from 9\% in February 2014 to 19\% in May 2015. ${ }^{7}$ New small car sales nationwide have plummeted from 213,444 in 2013 , to just 46,546 in $2015 .{ }^{8}$

And yet, while the country's economy nosedives, Ukrainian politicans are finding new ways to implement what can only be termed a suicidal economic policy. Here are just a few notable examples:

- For most of the past decade, $90 \%$ of the high value-added goods produced by Ukraine were sold to Russia. These include machinery, military technology, engines and motors. In 2014 , sales to the Russian market accounted for $44 \%$ of all machinery and appliances sold abroad. ${ }^{9}$ That same year, however, the government decided to tear up its defense contracts with Russia. As a result, Ukraine's defense and aviation industries lost more than $80 \%$ of their income, an estimated 2 billion hryvnia annually (at the time more than

\footnotetext{
${ }^{4}$ Yuri Poluneev, "Ukraine: Ten shocks," Studies in Applied Economics, No. 27 (March 2015): 7, Johns Hopkins Institute for Applied Economics, Global Health, and Study of Business Enterprise, http://krieger.jhu.edu/iae/economics/Yuri_Poluneev_Ukraine_Ten_Shocks.pdf.

5 “Transgranichnye denezhnye perevody v Ukrainu v 2015 godu upali na 35\%", Ukrainskii vybor, 9 March 2016, http://vybor.ua/news/transgranichnye_denejnye_perevody_v_ukrainu_v_2015_godu_upali_na_35.html (accessed 26 March 2016).

${ }^{6}$ Pilar Bonet, "La corrupción y la crisis económica amenazan con colapsar Ucrania", El Pais, 15 February 2016, http://internacional.elpais.com/internacional/2016/02/14/actualidad/1455484596_624760.html (accessed 26 March 2016).

${ }^{7}$ Denys Seleznev, "Sotsiologiya maidana: kak menyaetsya mnenie grazhdan Ukraine o perevorote 2014 goda", Ukraina.ru, 26 February 2016, http://ukraina.ru/analytics/20160226/1015727590-print.html (accessed 26 March 2016).

8 "Prodazhi legkovushek v Ukraine za god sokratilis vdvoe", Vesti Ukrainy, 4 January 2016, http://business.vestiukr.com/130727-prodazhi-legkovyh-avto-v-ukraine-za-god-sokratilis-vdvoe (accessed 26 March 2016).

${ }^{9}$ Mikhail A. Molchanov, “Choosing Europe over Russia: what has Ukraine gained?", European Politics and Society 17, No. 3 (2016): 385.
} 
\$200 million). ${ }^{10}$ Industrial giants like Yuzhmash, Motor Sich, Turboatom, and AvtoKrAZ

have all had to sharply scale back production, while the pride of Ukrainian industry, airline manufacturer Antonov, was liquidated and it assets transferred to another state-owned conglomerate in January 2016. ${ }^{11}$

- In January 2016 Ukrainian president Petro Poroshenko congratulated his countrymen on having survived the winter without Russian gas. It had gotten by instead with European reverse gas which, he pointed out proudly, was $30 \%$ more expensive than the spot price for Russian gas. ${ }^{12}$

Poroshenko's note of pride presumably stems from his countrymen enduring the burden of an additional $\$ 300-550$ million in annual payments for gas in order to end Ukraine's energy dependence on Russia. Indeed, prime minister Yevegny Yatseniuk cited "energy independence from Russia" as one of the government's major achievements in $2015 .{ }^{13}$

\footnotetext{
10 "Poteri Ukrainy ot razryva kontraktov c RF v kosmicheskoi i voennoi otraslyakh sostavyat 2 mlrd hrn", Ukrainskii vybor, 9 february 2016, http://vybor.ua/news/poteri_ukrainy_ot_razryva_kontraktov_s_rf_v_kosmicheskoy_i_voennyh_otraslyah_sostavyat 2_mlrd_grn.html (accessed 26 March 2016).

11 "Rozovye mify i chernaya realnost", Ukrainskii vybor, 23 march 2016, http://vybor.ua/article/grazhdanskoe_obschestvo/rozovye-mify-i-chernaya-realnost-mif-pervyy.html (accessed 26 March 2016); “Ukrainskii aviakontsern 'Antonov' likvidirovan”, Ukraina.ru, 27 January 2016, http://ukraina.ru/news/20160127/1015433629.html (accessed 26 March 2016).

12 "Reformi v energetitsi zabezpechuyut energetichnu nezalezhnist derzhavi--Prezident na Rivnenskii AES", Official Site of the President of Ukraine, 29 January 2016, http://www.president.gov.ua/news/reformi-v-energeticizabezpechuyut-energetichnu-nezalezhnist-36684 (accessed 26 March 2016); Viktor Medvedchuk, "Sotni millionov dollarov ubytkov--tsena 'gazovoi nezavisimosti'”, Ukrainskii vybor, 5 February 2016, http://vybor.ua/article/sistemnye_problemy_gosudarstvennosti/sotni-millionov-dollarov-ubytkov-cena-gazovoynezavisimosti.html (accessed 26 March 2016).

13 “Yatsenyuk: Ukraina slezla s 'gazovoi igly’ Rossii”, Segodnya, 29 December 2015, httpr://www.segodnya.ua/economics/enews/yacenyuk-ukrainy-slezla-s-gazovoy-igly-rossii-679402.html (accessed 26 March 2016).
} 
What both failed to mention, however, was that Ukraine's major European supplier of natural gas last year was Slovakia, which receives $90 \%$ of its gas from Russia. ${ }^{14}$ In effect, therefore, Ukraine was purchasing the very same Russian gas at a premium merely for the privilege of not having to call it Russian.

- In 2014 Ukraine decided to stop buying coal from the rebel-held territories of Donbas, the country's traditional supplier. Such coal purchases were denominated in hryvnia and were thus far cheaper than coal that could be purchased from abroad.

To show its independence from the rebels, however, Kiev decided that it would import coal from South Africa instead. ${ }^{15}$ Alas, as with the case of the Slovakian gas that actually comes from Russia, an investigation by Ukrainska pravda revealed that much of the coal purported to be from South Africa was actually Donbass coal, repackaged as South African through a Hong Kong company, then resold to Ukraine. ${ }^{16}$ As a result, the government not only paid more for coal, but lost tax revenues from Donbass as well.

- In 2014 Prime Minister Arseniy Yatsenyuk unveiled a \$517 million plan to reinforce Ukraine's border with Russia. ${ }^{17}$ Immediatey dubbed "The Great Wall of Ukraine," critics

\footnotetext{
${ }^{14}$ Kenneth Rapoza, "Ukraine Boasts European Gas Imports, But Most Of It Still Russian,” Forbes, 2 February 2016, http://www.forbes.com/sites/kenrapoza/2016/02/02/ukraine-boasts-european-gas-imports-but-most-of-it-stillrussian/\#62604fec30f6 (accessed 26 March 2016).

15 "Ukraine to cut financial ties to rebel-held Donbass", BNE Intellinews, 17 November 2014, http://www.rintellinews.com/ukraine-to-cut-financial-ties-to-rebel-held-donbass-500440902/?archive=bne (accessed 26 March 2016).

${ }^{16}$ Matvii Nikitin and Roman Kirichenko, “Operatsiya 'Legalizatsiya”. Yak Medvedchuk i Ko 'vPARyuyut' vugillya Ukraini”, Ukrainska pravda, 3 February 2016, http://www.pravda.com.ua/articles/2016/02/3/7097702/ (accessed 26 March 2016).

${ }^{17}$ Damien Sharkov, "Ukraine's 'Great Wall' With Russia to Start Building in Weeks", Newsweek, 15 March 2016, http://www.newsweek.com/ukraines-wall-russia-start-construction-luhansk-within-weeks-437103 (accessed 26 March 2016).
} 
pointed out that the proposed two meter high chain link fence and trenches would be of no value whatsoever against a Russian attack. Former prime minister Yulia Timoshenko even compared it to the Maginot and Mannerheim lines, pointing out that not a single military specialist supported it. ${ }^{18}$ For Yatseniuk, however, its ideological significance overshadowed its military significance. A wall on the Russian border, he pointed out, was much more than a mere physical barrier. "This" he pledged, "will be the eastern border of Europe." 19

But initial cost estimates have proved to be wildly off target. As a result, the project is stalled with less than 10 percent of it completed, mostly in the regions of Ukraine furthest from the fighting. ${ }^{20}$ Nevertheless, according to press reports, construction is to begin again in March of $2016 .^{21}$

One could add to this list a wide array more minor irritants, such as the abrupt cancellation of direct airline flights between the two countries; the banning of hundreds of Russian films and most Russian cable channels; the damaging the electricity pylons that deliver electricity to Crimea from Ukraine by Tatar and right wing activists; ${ }^{22}$ and the promotion of a

\footnotetext{
18 “Timoshenko raskritikovala stroitelostvo 'Steny' na granitse Ukrainy c Rossiei”, Newsru.com, 13 October 2014, http://txt.newsru.com/world/13oct2014/timoshenko.html (accessed 26 March 2016).

${ }^{19}$ Fred Weir, "Walled off: In non-rebel eastern Ukraine, frustrations with Kiev mount", Christian Science Monitor, 22 April 2015, http://www.csmonitor.com/World/Europe/2015/0422/Walled-off-In-non-rebel-eastern-Ukrainefrustrations-with-Kiev-mount (accessed 26 March 2016).

${ }^{20}$ By comparison, U.S. presidential candidate Donald Trump has estimated the cost of a wall on the US-Mexico border at $\$ 8$ billion. The wall Trump has proposed would be comparable in length, but much higher and sturdier than the Ukrainian wall. Even so, his estimates are widely regarded as much too conservative. See Glenn Kessler, "Trump's dubious claim that his border wall would cost $\$ 8$ billion”, The Washington Post, 11 February 2016, https://www.washingtonpost.com/news/fact-checker/wp/2016/02/11/trumps-dubious-claim-that-his-border-wallwould-cost-8-billion/ (accessed 26 March 2016).

${ }^{21}$ Sharkov, "Ukraine's 'Great Wall' With Russia".

${ }^{22}$ According to one of the blockade's organizers, Mustafa Dzhemilev, these actions were coordinated with president Poroshenko, see "Blokada Kryma: energomost", Analitik, 9 December 2015, http://www.analitik.org.ua/currentcomment/int/5666ddb7f409f/_accessed 26 March 2016). They were implemented by the volunteer btatallions of Azov, the Right Sector, and Tatar activists, see "Blokada Kryma: sobytiya proshloi nedeli", Analitik, 16 December 2016, http://www.analitik.org.ua/current-comment/int/567122cfec2ae/ (accessed 26 March 2016).
} 
vastly more expensive and cumberson alternative transportation route to China, just so that it does not pass through Russian territory. ${ }^{23}$ While these do not entirely bloc commerce, they either add to the cost of production or expand the black market, to the overall detriment of the Ukrainian economy.

A common thread linking the government's economically irrational behavior is the desire to spite Putin. Alas, it is the average Ukrainian citizen who must pay the price.

\section{What Went Wrong?}

It would be easy to blame the IMF and World Bank for Ukraine's current economic doldrums, and many in Ukraine do. Both anticipated that economic growth in Ukraine would begin in 2015 , when it actually fell by nearly $10 \%{ }^{24}$ Even more important, however, is that these initial estimates provided the rationale for the $\$ 17$ billion bailout package that was provided to Ukraine in 2014, which became $\$ 35$ billion when the program was launched in May 2014, and $\$ 55$ billion six months later. ${ }^{25}$

Even this figure now seems insufficient. Adding up the total cost of bailing out Ukraine's banks, paying off its external debts, paying for energy imports, and defending the national

\footnotetext{
23 “Ukrainskii poizd 'Shovkovogo shlyakhu' zastryag u Kitai: nemae zamovlen”, Ekonomichna pravda, 28 March 2016, http://www.epravda.com.ua/news/2016/03/28/586961/ (accessed 30 March 2016).

${ }^{24}$ The World bank expected 2.5\% GDP growth in 2015; the IMF 1.5\% GDP growth in 2015. Natalia Zinets, "War may delay Ukraine's economic growth until 2016- world bank", Reuters, 2 October 2014, http://www.reuters.com/article/ukraine-crisis-worldbank-idUSL6N0RX1MZ20141002 (accessed 26 March 2016); Elliott Auckland, "Ukrainian Economy Collapses In Third Quarter", Russian Insider, 20 October 2014, http://russiainsider.com/en/politics_ukraine_business/2014/11/04/02-04-48pm/ukrainian_economy_collapses_third_quarter (accessed 26 March 2016); “Ukraine's Economy Plummeted By Nearly 10 Percent In 2015”, Radio Free Europe/Radio Liberty, 25 March 2016, http://www.rferl.org/content/urkaine-economy-plummeted-nearly-10percent-2015-financial-consumer-implosion/27627512.html (accessed 26 March 2016).

${ }^{25}$ Desmond Lachman, “Is Ukraine another bottomless pit?” The Hill, 24 September 2014, http://thehill.com/blogs/pundits-blog/finance/218718-is-ukraine-another-bottomless-pit (accessed 26 March 2016).
} 
currency, Volodymyr Lanovoy, former president Kravchuk's economic minister, estimates that the total cost of subsidizing the Ukranian economy may come to well over $\$ 100$ billion. $^{26}$

To be fair, however, Western assumptions about Ukraine's speedy recovery were based on a quick end to the conflict in Eastern Ukraine and the resumption of normal trade relations with Russia. Almost no one anticipated that the conflict would drag on, and that Ukraine would douse its own burning house with fuel by cutting itself off from its largest investor--in the first 11 months of 2015 Ukraine's exports Belarus fell by $48 \%$, and to Russia by $53 \%{ }^{27}$

But what about the Deep and Comprehensive Free Trade Agreement (DCFTA) with the European Union (EU), the issue that inspired so many to support the Euromaidan? Sadly, the reality has fallen far short of Ukrainian expectations. The EU currently maintains tariff rate quotas (TRQs) on 36 groups of products, most notably in agriculture, which include some of Ukraine's main exports to the EU. In 2014-2015 Ukrainian exporters were able to fully utilize only six of these quotas. Inability to meet EU certification requirements is one reason. Another is that demand in Europe for Ukrainian products is simply too low. ${ }^{28}$ As a result, in 2015, when Ukrainian exports to the EU benefited from the temporary suspension of quotas from April through the end of the year, Ukrainian exports to the EU actually fell by $23 \%{ }^{29}$ In other words, the new Ukrainian government severed ties with its traditional market without gaining comparable access to new markets!

\footnotetext{
${ }^{26}$ Auckland, "Ukrainian Economy Collapses In Third Quarter".

${ }^{27}$ Viktor Medvedchuk, "Torgovlya Ukrainy c ES--razvenchanie mifa evrointegratorov", Ukrainskii vybor, 22 January 2016, http://vybor.ua/article/vneshnjaja_politika/torgovlya-ukrainy-s-es-razvenchanie-mifaevrointegratorov.html (accessed 26 March 2016).

${ }^{28}$ Molchanov, "Choosing Europe over Russia": 388.

${ }^{29}$ Yuliana Romanishin, "Chto pomozhet bolshe prodavat v Evropu?" Ukrainska pravda/Ekonomicheskaya pravda, 11 March 2016, http://www.epravda.com.ua/rus/publications/2016/03/11/584736/ (accessed 26 March 2016).
} 
Yet, at the height of the Euromaidan, pursuing business-as-usual with Russia was often portrayed as no different than a making pact with the devil, while the benefits of EU association were wildly oversold. With two years of EU integration in practice to look back upon, we can now make some real world comparisons.

Studies favoring EU association typically acknowledge some short term economic decine, as the country transitions to EU standards, but insist that over the long term the economic benefits of far outweigh those of joining the EEU. ${ }^{30}$

But even on this point there is considerable disagreement. Some studies estimated that no more than $15 \%$ of Ukrainian exports originally destined for the Eurasian Economic Union (EEU) before 2014 could be redirected elsewhere ${ }^{31}$ According to a study done in 2011, preferential energy pricing for Ukraine (at the rate being offered to Belarus) would have saved Ukraine \$3-6 billion a year in Russian energy imports, while increasing exports by $\$ 5-9$ billion a year. ${ }^{32}$ Other economists insisted that the benefits of maintaining Ukraine's existing technological integration within the EEU, and of keeping trade in one's national currency, significantly increases long term projected GDP growth. Most importantly, however, nearly all studies favoring EU association assume that trade ties with Russia and the EEU would remain unchanged after the DCFTA enters into effect when, in fact, the suspension of Ukraine's trade privileges have cost the country an estimated $\$ 3$ billion a year. ${ }^{33}$

\footnotetext{
${ }^{30}$ Movchan and Giucci, for example, suggest that joining the EEU would reduce the welfare of Ukrainians by 3.7\% in the long term, while signing the DCFTA would increase it by $11.8 \%$. V. Movchan and R. Giucci, "Quantitative assessment of Ukraine's regional integration options: DCFTA with European Union vs. Customs Union with Russia, Belarus and Kazakhstan", Policy Paper PP/05/2011. Berlin/Kyiv: German Advisory Group and Institute for Economic Research and Policy Consulting. Cited by Molchanov, "Choosing Europe over Russia": 386.

${ }^{31}$ Molchanov, "Choosing Europe over Russia": 389.

${ }^{32}$ Molchanov, "Choosing Europe over Russia": 385.

${ }^{33}$ P. Demicco, "When choosing means losing: The Eastern partners, the EU and the Eurasian Economic Union," Brussels: European Parliament, (2015). Cited by Molchanov, "Choosing Europe over Russia": 389.
} 
This is money that the limited trade preferences afforded Ukraine under the DCFTA could not hope to make up, nor was it ever intended to. At best, it can only partially compensate for lost markets, though that impact will be within a much longer timeframe.

According to a study done by the Oxford Economics group in July 2012, i.e. well before the events that led to the EuroMaidan, the total cumulative effect of the DCFTA for Ukraine could reach $3.3 \%$ of GDP by $2025 .{ }^{34}$ Meanwhile, however, several Russian economists put the estimated loss to Ukraine from sanctions, trade disputes, hostile press that affects labor migration, tourism, and Russian investment at as much as $\$ 33$ billion dollars annually, nearly a fifth of its 2013 GDP. ${ }^{35}$

Under any scenario, therefore, the Russian market is crucial. It was certainly never expected, at least within the EU, that its market would totally replace the Russian market. ${ }^{36}$ As Oleksandr Shepotylo, an economist who sees much greater long term growth potential for Ukraine in the DCFTA, and therefore favored its ratification, points out, Ukraine severely underexports to Russia. As a result, its highest growth potential, at least in the short term, lay within the EEU. His conclusion: "So long as Ukraine does not worsen its market access to

\footnotetext{
34 "Economic Impact of a Deep and Comprehensive FTA between the EU and the Ukraine", Oxford Economics (2012): 122-123. http://www.oxfordeconomics.com/my-oxford/projects/128886. Cited by Poluneev, "Ukraine: Ten shocks,": 4.

${ }^{35}$ E. Vinokurov, S. Kulik, A. Spartak, and I. Yurgens, "Tupik borby integratsii v Evrope (analiticheskii doklad)" Voprosy ekonomiki, 8, (2014): 4-25. Cited in Molchanov, "Choosing Europe over Russia": 389.

${ }^{36}$ See, for example, the telling difference between Ukraine's Minister of Agriculture, Mykola Prysyazhnyuk's, description of the DCFTA as providing an immediate increase in agricultural exports to the EU markets, in contrast to the much more somber assessement of Polish analysts that, "in reality, the agreement with the EU would not have created better export opportunities for Ukraine's agricultural products" at least in the short term. "The transformation of agriculture in Ukraine: From collective farms to agroholdings," Polish Centre for Eastern Studies $(O S W), 7$ February 2014, http://www.osw.waw.pl/en/publikacje/osw-commentary/2014-02-07/transformationagriculture-ukraine-collective-farms-to_(accessed 26 March 2016).
} 
Russia, it would be best to expand its trade to the EU and EEU alike under the DCFTA-EU scenario." ${ }^{37}$

The paradox of signing a DCFTA without preserving access to the Russian market, as the former government warned, is that Ukraine would be caught between low quotas and the lack of financing to achieve the certification needed to even reach those quotas. On items like sugar, the government has not allocated funding for the certifying institution for the past three years, so there is actually no one to certify that Ukrainian sugar meets EU standards. ${ }^{38}$ All of this led president Poroshenko's former deputy chief of staff, Yuri Kosyuk, to complain earlier this year that, "Three has been no opening of markets ... it's been a "free trade zone" that is only one way. ${ }^{39}$

This view has become more common in Ukraine in recent months, and along with it, a perceptible rise in the number those opposed to joining either the EU or the EEU. ${ }^{40}$ Their frustration is understandable, but misplaced. The EU's first priority must obviously be to its own markets and its own producers. It is more difficult, however, to understand the logic of Ukraine's president, who in January 2016 revealed his far reaching plans to abandon some of Ukraine's largest export industries, including manufacturing and industry, and shift government support to

\footnotetext{
${ }^{37}$ O. Shepotylo, "Export potential, uncertainty, and regional integration: Choice of trade policy for Ukraine”, Social Science Research Network (2013), http://ssrn.com/abstract=2288652. Cited by Molchanov, "Choosing Europe over Russia": 386.

${ }^{38}$ Viktor Medvedchuk, "Polnyi proval ZST c ES dlya Ukrainy stanovitsya ochevidnym", Ukrainskii vybor, 19 January 2016, http://vybor.ua/article/economika/polnyy-proval-zst-s-es-dlya-ukrainy-stanovitsya-ochevidnym.html (accessed 26 March 2016).

${ }^{39}$ Ibid.

40 "Za god kolichestvi storonnikov evrointegratsii sredi ukraintsev umenshilos--issledovanie", UNIAN, 11 March 2016, http://www.unian.net/society/1287630-za-god-kolichestvo-storonnikov-evrointegratsii-sredi-ukraintsevumenshilos-issledovanie.html (accessed 26 March 2016).
} 
information technologies and agriculture, in the hopes of creating a new export base that will be more attractive to European consumers. ${ }^{41}$

As already pointed out, the EU's tariff rate quotas (TRQs) are designed precisely to prevent the unfettered access of Ukrainian agricultural products to the European market, and EU officials have shown no inclination to renegotiate them. Nor is it clear where the government intends to get the money needed to make Ukrainian agriculture more globally competitive. The total cost of modernizing Ukrainian agriculture and implementing EU standards has been estimated at over $\$ 1$ billion over the next ten years. ${ }^{42}$ Yet, as economists Frey and Olekseyuk point out, even with substantial cutbacks in social spending, or a massive infusion of additional foreign aid, "food-processing and production of non-metallic mineral prodcuts, agriculture, fishery ... reduce their output in all simulations [emphasis added --NP] because of a high initial level of protection and low export shares." ${ }^{43}$

It is becoming apparent that the government's insistence on punishing Russia at the expense of economic rationality poses a profound threat to the government's authority and to Ukraine's national security. $70 \%$ say country is on wrong track. ${ }^{44} 85 \%$ say they do not trust prime minister Yatsenyuk. ${ }^{45} 71 \%$ say no real reforms are taking place. ${ }^{46}$ Shockingly, president Poroshenko's popularity is now lower than that of his predecessor on the eve of the Maidan

\footnotetext{
41 "Press-konferentsiya P. Poroshenko", Analitik, 18 January 2016, http://www.analitik.org.ua/currentcomment/int/569ce39ab63b9/ (accessed 26 March 2016).

${ }^{42}$ Molchanov, "Choosing Europe over Russia": 388.

${ }^{43}$ Ibid.

44 "Opros: Bolee 70\% zhitelei Ukrainy ne odobryayut politiku Poroshenko", Regnum, 23 February 2016, http://regnum.ru/news/polit/2084761.html (accessed 26 March 2016).

${ }^{45}$ Viktor Medvedchuk, "Zakat evrointegratsii", Ukrainskii vybor, 25 February 2016, http://vybor.ua/article/vneshnjaja_politika/zakat-evrointegracii.html (accessed 26 March 2016).

${ }^{46}$ Medvedchuk, "Zakat evrointegratsii".
} 
rebellion that ousted him. ${ }^{47}$ As former president Yushchenko remarked, catachrestically, "I can hear the smell of burning tires $\$ 48$

The government's supporters, however, insist that they cannot change course.

First, they say, politically Ukraine has no choice but to respond to Russian aggression by imposing its own sanctions. The beauty of this argument is that, while it may not make economic sense, it makes a great deal of political sense for those now in power. Before 2014, foreign investment was not only largely from Russia, or from countries like Cyprus and the British Virgin Islands that serve as havens for Russian capital, it was also heavily concentrated in the Russian speaking industrial regions of Ukraine--Kiev, Dnepropetrovsk, Donetsk, and Kharkov. ${ }^{49}$ Cutting off this Russian investment therefore disproportionately affects these regions. The destruction of Ukraine's industrial base thus shifts the balance of economic and political power from the eastern to the western regions, thereby permanently marginalising the opposition, whose power base lies in the East.

Second, they insist that a large part of Ukraine's current economic contraction should be attributed to the conflict in Donbass and the loss of Crimea. It is certainly true that these conflicts have taken a dramatic toll on Ukraine's economy. The government estimates the total loss at as much as $20 \%$ of GDP, not including the sharp rise in military spending. ${ }^{50}$

\footnotetext{
${ }^{47}$ Julie Ray, "Ukrainians Disillusioned With Leadership", Gallup, 23 December 2015, http://www.gallup.com/poll/187931/ukrainians-disillusioned-leadership.aspx (accessed 26 March 2016).

${ }^{48}$ Nataliya Dvali, "Yushchenko: Budet li tretii Maidan? Ya slyshu zapakh goryashchikh shin", Gordon, 26 February 2016, http://gordonua.com/publications/yushchenko-budet-li-tretiy-maydan-ya-slyshu-zapah-goryashchih-shin122029.html (accessed 26 March 2016).

${ }^{49}$ Molchanov, "Choosing Europe over Russia": 389.

${ }^{50}$ Alya Shandra, "Ukrainian government created Black Book of Kremlin's crimes against Ukraine", EuroMaidan Press, 18 February 2015, http://euromaidanpress.com/2015/02/18/ukrainian-government-created-black-bookkremlins-crimes-ukraine/\#arvlbdata (accessed 30 March 2016).
} 
But even without entering into the controversial subject of who is more to blame for these conflicts, it is worth noting that Donbass and Crimea were both net recipients of budgetary transfers. Thus, ending government subsidies to their industries, as Yatsenyuk liked to point out before 2014, when he was a leader of the opposition, would improve the government's balance sheet, not worsen it. ${ }^{51}$

Finally, they continue to insist that the country will ultimately be bailed out by the West because the latter simply have no other choice. As Poroshenko put it in his 2014 speech to a joint session of the U.S. Congress, the conflict in Ukraine is one between "civilization and barbarism.. ${ }^{, 52}$ The concerns about Ukraine's ability reform itself being voiced by even noted supporters, like former U.S. Secretary of State Condi Rice, and the current U.S. ambassador to Ukraine, Geoffrey Pyatt, seem to have had remarkably little impact on this assumption. ${ }^{53}$

\section{Why There is No Alternative to Russia}

This is not to suggest that the government has accomplished nothing, though most of what it has accomplished could perhaps most generously be described as laying the foundations for future economic growth. ${ }^{54}$

\footnotetext{
${ }^{51}$ Karpyuk, "Kiev i separatisty nashli povod dlya dialoga."

${ }^{52}$ Paul D. Shinkman, "Ukrainian President: Russian Aggression Sparking New Cold War", U.S. News \& World Report, 18 September 2014, http://www.usnews.com/news/articles/2014/09/18/ukrainian-president-petroporoshenko-russian-aggression-sparking-a-new-cold-war (accessed 26 March 2016).

${ }^{53}$ Sergei Sidorenko, "Kondoliza Rais: Ukraina delaet odnu revolyutsiyu za drugoi. Mozhet pora upravlyat gosudarstvom?" Evropeiska pravda, 14 March 2016, http://www.eurointegration.com.ua/rus/interview/2016/03/14/7046142/view_print/(accessed 26 March 2016); Georgi Gotev, "US ambassador: 'Ukraine fatigue' in Europe is major risk for Kyiv", EurActiv, 4 March 2016, http://beta.euractiv.com/section/europe-s-east/news/us-ambassador-ukraine-fatigue-in-europe-is-major-risk-for-kyiv/ (accessed 26 March 2016).

${ }^{54}$ Fyodor Papaduik, "2015. Top-10 skromnykh dostizhenii Ukrainy, o kotorykh stoit vspomnit", Ekonomichkaya pravda, 31 December 2015, http://www.epravda.com.ua/rus/publications/2015/12/31/574789/ (accessed 30 March 2016).
} 
Thus, Dragon Capital reports the good news that total foreign debt of Ukraine has shrunk for the second year in a row. Actually, however, public sector debt has increased, thanks to the loans made to the Ukrainian government. The decline in overall debt has been due mostly to the collapse of private sector lending and the inability of Ukrainian banks to obtain long term loans. $^{55}$

Ukraine has also increased its profits from transportation of natural gas in 2015, thanks to an increase in the volume of Russian gas going to Europe. Domestic gas consumption, however, continued to fall: from 50.4 billion cubic meters (bcm) in 2013, to $42.6 \mathrm{bcm}$ in 2014 , to $34.4 \mathrm{bcm}$ in 2013. While the government attributes this decline to greater efficiency, it is reasonable to assume that the steep rise in the costs for consumers and businesses has also contributed to this decrease. $^{56}$

Perhaps the government's best known accomplishment last year was the agreement to write off $20 \%$ its Eurobond debt. This allowed it to continue negotiations for another IMF loan tranche which, as of April 2016, it still has not received. But what is often overlooked are the draconian terms that Western creditors imposed for this delay in payment. Should Ukraine ever achieve an annual economic growth rate of $3-4 \%$, creditors will receive $15 \%$ of total GDP growth. Should its growth rate rise to more than $4 \%$, creditors will receive a whopping $40 \%$ of

\footnotetext{
55 "Vneshnii gosdolg Ukrainy vyros do istoricheskogo maksimuma", Ukrainskii vybor, 23 March 2016, http://vybor.ua/news/vneshniy_gosdolg_ukrainy_vyros_do_istoricheskogo_maksimuma.html (accessed $30 \mathrm{March}$ 2016).

${ }^{56}$ Oksana Matiek, “Rossiya proigrala gazotransportnuyu voinu Ukraine--'Ukrtransgaz'”, Oil Review, 28 March 2016, http://oilreview.kiev.ua/2016/03/28/rossiya-proigrala-gazotransportnuyu-vojnu-ukraine-ukrtransgaz/ (accessed 30 March 2016).
} 
each percent of growth! ${ }^{57}$ Under any circumstances, Ukraine will be paying interest on this debt through $2041 .^{58}$

There is a better way forward that could revive domestic living standards, promote national unity, and lead to a strengthening of Ukraine's international political and economic standing--the restoration of common sense economic ties with Russia.

Let me review briefly why Russia remains vital to the Ukrainian economy, even today.

Despite the fact that the percentage of Ukraine's trade with Russia has fallen by $53 \%$, two years into the current conflict Russia remains Ukraine's single largest trading partner. ${ }^{59}$ A study pubklished in Evropeiska pravda at the end of 2014 found that, even after the signing of the DCFTA, several regions of Ukraine actually became more dependent on Russian trade than they had been the previous year. ${ }^{60}$

In 2015 Russian ranked fourth among the Ukraine's top foreign investors. ${ }^{61}$ This, however, masks the true extent of Russian investement, since much of the remaining investment money comes from countries like Cyprus and the British Virgin Islands, which are well known shelters for Russian capital. ${ }^{62}$

Despite all the restrictions that are now imposed on Russian capital, a quarter of all Ukrainian bank deposits are still Russian banks (banks operating in Ukraine with Russian

\footnotetext{
${ }^{57}$ Papaduik, "2015. Top-10 skromnykh dostizhenii Ukrainy".

${ }^{58}$ Viktor Medvedchuk, "Narod nishchayet--pravitelstvo khvalitsya uspekhami”, Ukrainskii vybor, http://vybor.ua/article/economika/narod-nishchaet-pravitelstvo-hvalitsya-uspehami.html (accessed March 30, 2016).

${ }^{59}$ Mariya Golub and Lyubov Akulenko, "God vypolneniya Soglasheniya ob assotsiatsii: chto poteryalo pravitelstvo v 'evropeiskom' otchete”, Evropeiska pravda, 26 February 2016, http://www.eurointegration.com.ua/rus/articles/2016/02/26/7045453/ (accessed 26 March 2016).

60 "Vneshnaya torgovlya ukrainskykh regionov," Evropeiska pravda, 17 December 2014, http://www.eurointegration.com.ua/rus/articles/2014/12/17/7028821/ (accessed 26 March 2016).

61 "V 2015 godu inostrannye investitsii v Ukrainy sokratilis na 5,2\%", Ukrainskii vybor, 18 February 2016, http://vybor.ua/news/v_2015_godu_inostrannye_investicii_v_ukrainu_sokratilis_na_5_2.html (accessed 26 March 2016).

${ }^{62}$ Poluneev, “Ukraine: Ten shocks,": 6.
} 
capital) which is why, when right wing vigilantes began conducting pogroms of these banks in various Ukranian cities in 2016, the head of the Ukrainian National Bank went on national televisions and appealed to them to stop. ${ }^{63}$

Finally, as the Ukrainian economy shrinks, more and more families find themselves relying on remittances from migrant workers, the majority of whom still find work in Russia. ${ }^{64}$ Some five to seven million Ukrainians have left the country seeking work abroad, and in 2014 they remitted $\$ 9$ billion to the Ukraine, which is three times the total foreign direct investments Ukraine received last year. ${ }^{65}$ By some estimates the potential loss to the Ukrainian economy should migrant workers no longer be allowed to work in Russia could reach as high as \$11-13 billion, or 7\% of GDP. ${ }^{66}$

Ukraine cannot survive on Western bailouts alone; it desperately needs massive amounts of long term investment which, historically, only Russia has been willing to provide. Over the past twenty years the West has promised Ukraine almost $\$ 62$ billion in aid for reforms, primarily through loans from the IMF, European Union, and World Bank. The amount actually disbursed appears to have been less than half this amount, however, since these assistance programs were often suspended part way through due to Ukraine's failure to implement the suggested reforms. ${ }^{67}$

\footnotetext{
63 "Natsbank Ukrainy prinyal storonu rossiiskikh bankov", Ukraina.ru, 20 March 2016, http://ukraina.ru/news/20160320/1015931958.html (accessed 26 March 2016).

64 "Iz kakikh stran ukraintsy poluchayut dengi," Vesti Ukrainy, 1 April 2015, http://vesti-ukr.com/infografika/94626iz-kakih-stran-ukraincy-poluchajut-dengi (accessed 26 March 2016).

${ }^{65}$ Ivan Lizan, "Politekonomiya grazhdanskoi voiny: kak Ukraina za god obednela do urovnya Tadzhikistana," Odnako, 17 March 2015, http://www.odnako.org/blogs/politekonomiya-grazhdanskoy-voyni-kak-ukraina-za-godobednela-do-urovnya-tadzhikistana/ (accessed 26 March 2016); "Iz kakikh stran ukraintsy poluchayut dengi", Vesti Ukrainy, 1 April 2015, http://vesti-ukr.com/infografika/94626-iz-kakih-stran-ukraincy-poluchajut-dengi (accessed 26 March 2016); "V Ukrainy pridut mnogomilliardnye investitsii?" Ukrainskii vybor, 12 February 2016, http://vybor.ua/article/economika/v-ukrainu-pridut-mnogomilliardnye-investicii.html (accessed 26 March 2016). ${ }^{66}$ Dmitry Medvedev, "Rossiya i Ukraina: zhin po novym pravilam”, Nezavisimaya gazeta, 15 December 2014, http://www.ng.ru/ideas/2014-12-15/1_medvedev.html (accessed 26 March 2016).

${ }^{67}$ Galina Kalachova and Samira Abbasova, "Komu i skilki vinna derzhava Ukraina”, Ekonomichna pravda, 30 March 2016, http://www.epravda.com.ua/cdn/cd1/2016/03/mvf/index.html (accessed 6 April 2016).
} 
By contrast, according to Russia's Minister for Economic Development, Alexei Ulyukaev, Russia has put some $\$ 200$ billion into the Ukrainian economy over the course of the past two decades ${ }^{68}$ Separately, Russian prime minister Dmitry Medvedev estimated Ukraine's savings since 1990 on gas discounts alone at more than $\$ 80$ billion. ${ }^{69}$ Since the collapse of the Ukrainian economy is something that both Russia and the West say they are eager to avoid, it therefore makes eminent sense to forge a program for the economic recovery of Ukraine that they could implement together.

Some might object that any Ukrainian government will have a hard time finding support for such a policy, since the annexation of Crimea and the war in Donbass have so dramatically heightened anti-Russian sentiments in Ukraine. The truth, however, is that all the polls taken since the EuroMaidan continue to point to a deeply divided population. While negative attitudes towards Russia, and conversely support for the EU, have increased dramatically since May 2014, strong regional differences persist. For example, according to the latest Kiev International Institute of Sociology Survey, conducted 5-16 February 2016, overall 34\% of Ukrainians say have a "very positive" or "mostly positive" view of Russia, with a low of $21.2 \%$ in Western Ukraine, and a high of $55.1 \%$ in Eastern Ukraine. ${ }^{70}$

In another recent survey, when asked to state a preference for joining either the EU or the "Customs Union of Russia, Belarus and Kazakhstan," respondents in the Western cities of IvanoFrankivsk and Ternopil favored joining the EU by more than $90 \%$, while less than $30 \%$ of

\footnotetext{
68 “Skolko soten milliardov Rossiya vlozhila podarila Ukraina", Politicheskie Izvestia v Ukraine, 19 May 2014, http://izvestia.kiev.ua/article/67475 (accessed 6 April 2016).

69 “D. Medvedev podshchital, skolko mlrd doll SShA Rossiya podarila Ukraine", Neftegaz.ru, 10 December 2014, http://neftegaz.ru/news/view/133078 (accessed 6 April 2016).

${ }^{70}$ Tetyana Pyaskovska, "Changes in the attitude of the Ukrainians toward Russia and of the Russians toward Ukraine", Kiev International Instittue of Sociology, 11 March 2016, http://www.kiis.com.ua/?lang=eng\&cat=reports\&id=608\&page=1 (accessed 26 March 2016).
} 
respondents in the Southeastern citites of Mariupol and Severodonetsk felt the same way. And on the controversial issue of whether or not Ukraine should join NATO, results were even more sharply divided, with the "yes" vote getting the majority less than half of the 24 major cities surveyed. ${ }^{71}$ It is also important to point out that these surveys do not include the populations of Crimea and the portions of Donbass that are currently under rebel control. Their inclusion would presumably shift both regional and national survey results significantly in Russia's favor. ${ }^{72}$

In this context, it is particularly interesting to note that the country apparently most admired by Ukrainians is Belarus, and that the most widely admired foreign politician (the only one to get over 50\% approval in all four macroregions) is Belarussian president Alexander Lukashenka, a paragon of Soviet era stabilility. ${ }^{73}$ This suggests that a policy modelled on that of Belarus might be broadly popular across all regions of Ukraine.

[insert Chart 1: Regional Levels of Approval in Ukraine for Selected World Leaders]

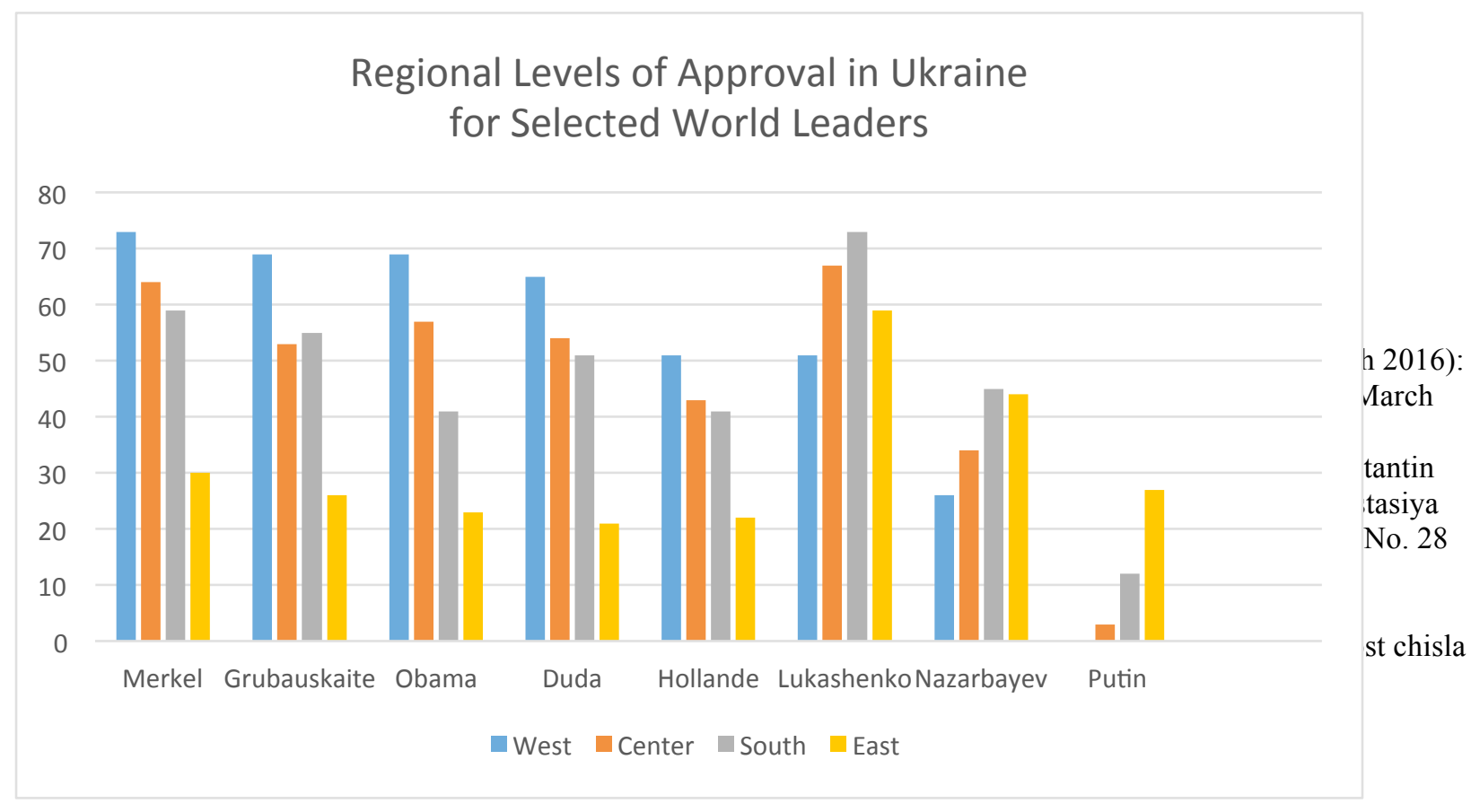


Chart 1 source: Taimer $^{74}$

Belarus highlights the "road not taken" by Ukraine and the EU in dealing with Russia. Despite the EU sanctions imposed upon its political leadership in 2004, many analysts note that the country has registered impressive economic growth, thanks to its association with the EEU and energy subsidies from Russia. ${ }^{75}$ With most EU sanctions lifted in February 2016, the country appears poised to take Ukraine's place as the main land corridor for trade between Russia and the EU.

\section{Helping Ukraine Help Itself}

Ukraine would benefit greatly from reaching a modus vivendi with Russia that is based on mutual economic interests.

\footnotetext{
74 “Lukashenko--lider simpatii zhitelei yuga Ukrainy," Taimer, 11 February 2016, http://timerodessa.net/news/lukashenko_lider_simpatiy_jiteley_yuga_ukraini_637.html (accessed 26 March 2016);

${ }^{75}$ Marek Dabrowski, "Belarus at a crossroads", Bruegel, 21 January 2016, http://bruegel.org/2016/01/belarus-at-acrossroads/ (accessed 26 March 2016); Euan Mearns, "Belarus grows while Ukraine withers," Energy Matters, 17 April 2014, http://euanmearns.com/belarus-grows-while-ukraine-withers/ (accessed 26 March 2016); "The future of Belarus is brighter than ever before", World Finance, 7 January 2016, http://www.worldfinance.com/infrastructure-investment/the-future-of-belarus-is-brighter-than-ever-before (accessed 26 March 2016).
} 
First, it would help to attract much needed investment in the countries transportation infrastructure. By the government's own estimates, some $90 \%$ of its railways, $90 \%$ of ports, abd $80 \%$ of roads are used up, while only $3-5 \%$ of Ukraine's road are currently safe to drive on. ${ }^{76}$ While 6 billion hryvnia have been allocated to road repair in the 2016 state budget, according to government analyst Roman Khmil, "the country needs to spend 50-100 million hryvnia annually for at least ten years." ${ }^{, 77}$ It does not make economic sense for the EU to invest this much in Ukrainian infrastructure (the proposed Via Carpathia transportation corridor, which will go around Ukraine rather than through it, is a reminder of that), but it would for Russia, if Ukraine were to restore normal economic relations with it. ${ }^{78}$

Second, it would promote national unity by showing that the Kiev values the industries based in the Eastern half of the country, and that its policies are not, in fact, aimed at marginalizing these regions. ${ }^{79}$ The fact that cross-border cooperation with Russia is specifically mentioned in the Minsk II Accords suggests that such ties are deemed essential to revitalizing Donbass and re-integrating it politically and culturally back into Ukraine. ${ }^{80}$

Finally, by demonstrating its willingness to govern in the best interests of all the people, rather than rely on a narrow base of ideological and geographical support, such a shift would

\footnotetext{
76 "V Ukraine iznosheno okolo 80\% dorog i 90\% zheleznodorozhnoi infrastruktury", Ukrainskii vybor, 31 January 2016, http://vybor.ua/news/v_ukraine_iznosheno_okolo_80_dorog_i_90_jeleznodorojnoy_infrastruktury.html (accessed 26 March 2016).

77 "Tolko 5\% ukrainskikh dorog otremontirovany i bezopasny dlya proezda", Ukrainskii vybor, 2 February 2016, http://vybor.ua/news/tolko 5 ukrainskih dorog otremontirovany i bezopasny dlya proezda.html (accessed 30 March 2016).

${ }^{78}$ Maksim Gardus, "Evropa stroit novuyu magistral v obyezd Ukrainy”, Apostrophe, 10 March 2016, http://apostrophe.com.ua/article/business/transport/2016-03-10/evropa-stroit-novuyu-avtomagistral-v-obyezdukrainyi-chem-eto-grozit-ekonomike/3662 (accessed 26 March 2016).

${ }^{79}$ Poroshenko's reluctance is described by journalist Sergei Rakhmanin in "Khozhdenie po minshomu polyu", Zerkalo nedeli, 11 March 2016, http://gazeta.zn.ua/internal/hozhdenie-po-minskomu-polyu-_.html (accessed 26 March 2016).

${ }^{80}$ See point 11, footnote 1, "Package of Measures for the Implementation of the Minsk Agreements", OSCE, 12 February 2015, http://www.osce.org/cio/140156 (accessed 30 March 2016).
} 
strengthen Ukraine's international political and economic standing, by giving international investors confidence that the government gives precedence to pragmatic necessity over ideology.

By contrast, the ambitious new economic strategy proposed by president Poroshenko in January would be slow to bear fruit even under the best of circumstance; the current fragility of the Ukrainian economy makes it all the more susceptible to political pressures and intrigue. Should the anticipated economic recovery be delayed much further, a restless populace is likely to shift blame to the West for ostensibly failing to provide adequate support to Ukraine. According to economist and former member of the Ukrainian parliament, Yuri Poluneev, this could result in a "huge social whiplash against Ukraine's EU aspirations."

What Ukraine needs most, therefore, is a good dose of common sense. Without it, no government or nation can long survive. This means the restoration of those economic ties with Russia that clearly benefit the Ukrainian economy, at least until Ukraine develops stable alternative markets.

To be clear, I do not see restoring economic ties with Russia as a panacea for all that ails Ukraine. I see it as a vital stop gap measure needed to stop the hemorrhaging of resources, manpower, and capital, and to win Ukraine time and breathing space for economic reform, and hopefully prevent the current economic crisis from turning into a political collapse.

Nor do I see it as a matter of chosing the Eurasian Economic Union over the EU. For Ukraine, with its deep cultural ties to both Europe and Russia, insisting on such a choice can

\footnotetext{
${ }^{81}$ Poluneev, "Ukraine: Ten shocks,": 9.
} 
only lead to civil strife. It is therefore a quintessentially false choice, as European leaders are slowly coming to realize. ${ }^{82}$

In order to unite the country, Ukrainian leaders must stop trying to pit one against the other, and instead embrace the idea of Ukraine becoming a conduit between these two huge markets. Ukraine should be the first to promote closer economic ties between the EU and EEU, because it stands to profit the most from such trade. Positioning itself as the vital link between the Eastern and Western halves of Europe would also be the best way to provide Ukraine with the leverage it needs to extract maximum benefits for itself.

Ultimately, appreciating the benefits of such mutual dependency may be the best hope for long term peace and prosperity, not only between Russia and Ukraine, but in all of Europe.

\footnotetext{
${ }^{82}$ See, for example, Theo Sommer, "Weder Russland noch Europa," Die Zeit, 8 March 2016, http://www.zeit.de/politik/ausland/2016-03/ukraine-eu-nato-mitgliedschaft-5vor8 (accessed 26 March 2016); "Ukraine-Russie: 1'absurde affrontement," Le Monde, 5 January 2016, http://www.lemonde.fr/idees/article/2016/01/05/ukraine-russie-1-absurde-affrontement_4841786_3232.html (accessed 26 March 2016).
} 